\title{
Preservice Teachers' Risk Perceptions and Willingness to Use Educational Technologies: A Belief System Approach
}

\author{
Mehmet Demirbağ
}

\author{
Ahmet Kılınç***
}

\begin{abstract}
One of the beliefs that is responsible for teachers' resistance to educational technologies (Ets) is risk perceptions. Risk psychology scholars describe risk perception as people's informal estimation of the probability of an event happening combined with an evaluation of how concerned they would be about the negative consequences of such an incident. About the nature of risk perceptions, three theoretical explanations have been put forwarded: cultural theory, affect heuristic and psychometric paradigm. Because cultural theory has limited predictive power in the empirical research and because affect heuristic not only covers risks but also contains benefits, we focus mainly on psychometric paradigm in the present study. The psychometric paradigm emphasizes that risk is a combination of many factors such as knowledge, dread, control, catastrophic potential, equity, voluntariness and tamper with the nature. The purpose of present study was to understand the predictive power of risk perceptions for pre-service teachers (PTs)' willingness to use Ets. We developed a questionnaire covering three sections: personal information, willingness to use Ets and risk perceptions. We administered this questionnaire to 425 Turkish PTs from different backgrounds (STEM and non-STEM branches). We benefited from factor analysis and hierarchical regression for data analyses. The results of factor analyze showed that six dimensions (dread, unnatural consequences, negative impacts on learning, noneducational purposes, traditional education and first-time use) constituted the PTs' risk perceptions. The regression results showed that certain risk perception dimensions were predictors of willingness to use Ets. At the end of the paper, we suggested implications based on enhancement strategies for teacher epistemology and risk mitigation opportunities.
\end{abstract}

Keywords: risk perceptions, willingness to use educational technologies, preservice teachers, belief system

\footnotetext{
* Correspondence Author: Dr., Bursa Uludag University, Faculty of Education, Department of Mathematics and Science Education, Bursa, Turkey. E-mail: mtdemirbag@gmail.com

** Prof. Dr., Bursa Uludag University, Faculty of Education, Department of Mathematics and Science Education, Bursa, Turkey.E-mail: akilinc@uludag.edu.tr
} 


\title{
Öğretmen Adaylarının Eğitim Teknolojileri Kullanımına Yönelik İstekliliği ve Risk Algıları: Bir İnanç Sistemi Yaklaşımı Çalışması
}

\author{
$\ddot{\mathbf{O} z}$
}

\begin{abstract}
Öğretmenlerin eğitim teknolojilerine direnç göstermelerinden sorumlu inançlardan birisi de risk algılarıdır. Risk psikolojisi uzmanlarına göre bireyler risk algısını, bir olayın meydana gelme olasıllğı ve böyle bir olayın olumsuz sonuçları hakkında ne kadar endişe duydukları ile ilgili bir değerlendirmeyle birlikte tanımlar. Risk algılarının doğası hakkında üç teorik açıklama ileri sürülmüştür. Kültürel teori, ampirik araştırmada sinırlı yordayıc1 güce sahip olduğundan, duygusal-sezgi (affect heuristic) teori ise riskleri kapsamakla kalmayıp aynı zamanda faydaları da içerdiği için, bu çalışmada temel olarak psikometrik paradigmaya odaklanılmıştır. Psikometrik paradigma, riskin bilgi, korku, kontrol, yıkıcı potansiyel, eşitlik, gönüllülük ve doğaya müdahale gibi birçok faktörün bir bileşimi olduğunu vurgular. Bu çalışmanın amacı, risk algılarının öğretmen adaylarının eğitim teknolojilerini kullanma istekliliğini yordama gücünü anlamaktır. Bu amaçla kişisel bilgiler, eğitim teknolojilerini kullanma istekliliği ve risk algıları olmak üzere üç bölümden oluşan bir anket geliştirilmiştir. Bu anket, farklı branş geçmişine sahip (STEM ve STEM dış şubeler) 425 öğretmen adayına uygulanmıştır. Veri analizi için faktör analizi ve hiyerarşik regresyondan yararlanılmıştır. Faktör analizi sonuçları, korku, doğal olmayan sonuçlar, öğrenmeyle ilgili olumsuz etkiler, eğitim dış1 amaçlar, geleneksel öğretim ve ilk kez kullanım alt boyutlarının öğretmen adaylarının risk algılarını oluşturduğunu göstermiştir. Regresyon sonuçları ise bazı risk algılama boyutlarının eğitim teknolojilerini kullanma istekliliğini yordadığını göstermiştir. Araştırmanın sonunda, öğretmen epistemolojisini geliştirme ve riski azaltma firsatlarına yönelik önerilerde bulunulmuştur.
\end{abstract}

Anahtar Sözcükler: risk algıları, eğitim teknolojilerini kullanma isteği, öğretmen adayları, inanç sistemi 


\section{Introduction}

Technology-oriented knowledge, skills and values are an important part of current life. Not only the daily activities, but also professional lives are invaded by constantly changing technologies. These realities have triggered many governments around the world to incorporate technology-based learning outcomes into national curricula (Organization for Economic Cooperation and Development [OECD], 2015). They have also produced certain international standards for technology-integrated schools (International Society for Technology in Education [ISTE], 2008).

In parallel with these developments, governments have invested enormous money to equip classrooms with recent educational technologies (Ets) (National Education Association [NEA], 2008). Even though they have been very successful in these infrastructure-based policies, they have experienced a strong barrier in reaching technologically literate citizens: Teachers (Howard, 2013). Teachers easily produce resistance when their belief systems do not comply with the reform's necessitates (Rodriquez, 2005). In the case of technology integration, many teachers produce resistance to technology-oriented reforms either by not using Ets in the classrooms or by using technologies in a superficial way (OECD, 2015).

One of the beliefs producing resistance to technology integration is risk perceptions (Howard, 2013; Kilinc et al., 2016). Risk perceptions are beliefs about risk of something or some case that has the potential to happen (Sjöberg, Moen \& Rundmao, 2004). Even though there is limited research, we can argue that teachers with high risk perceptions about Ets use are not willing to change their teaching habits and do not put technology-based reforms into practice (Earle, 2002; Howard, 2011, 2013, Kilinc et al., 2016; Timucin, 2009).

Taken together, it is important to study teachers' beliefs about risks of Ets use considering huge investments around the world, important goals about technologically literate citizens and unintended results about teacher's resistance.

\section{Theoretical Frame work}

Teachers' belief syste $m s$ and resistance to change

Rokeach (1968) defined belief as "any simple proposition, conscious or unconscious, inferred from what a person says or does" (p.113). Teachers produce a range of beliefs about the self, teaching, student learning, knowledge and knowing (epistemologies) and Ets (Fives \& Buehl, 2012). These beliefs are included in a network (Kilinc, Demiral \& Kartal 2017). Kilinç et al. (2013), for example, have argued that there are central and peripheral beliefs in this network. Central beliefs have been developed through long-term experience and connected to many peripheral beliefs perhaps because of unbounded nature of beliefs (Abelson, 1979). Epistemologies, beliefs about student learning and teaching efficacy beliefs are the examples of these central beliefs (Fives \& Buehl, 2012; Kilinc et al., 2017). On the other hand, peripheral beliefs are built on central ones, are developed through short-term experience and used particularly for daily base decisions (Rokeach, 1968). Content-based teaching beliefs, beliefs about course planning and beliefs on how to integrate the technology into a unit can be examples of peripheral ones (Demirbag and Kilinc, 2015).

A teacher's belief system particularly come into play once s/he experiences an educational reform (Kilinc et al., 2017). When the reform is presented to teachers, they first experience a cognitive doubt and then make reflections on the gap between the expected changes and their belief systems (Rodriquez, 2005). If the reform efforts are not compatible with existing belief system and produce uncertainties, their chance to be put into practice by teachers shrinks (Rodriquez, 2005). In other words, teachers produce resistance to the reform. The position of beliefs in the same system is crucial in this process. Because central beliefs are harder to change than peripheral beliefs (Gill \& Fives, 2015) and because peripheral beliefs are contextualized on central beliefs (Kilinc et al., 2017), the reform efforts that are consistent particularly with core, central beliefs become successful (Lee \& Witz, 2009).

\section{Risk perceptions}

Risk psychology scholars describe risk perception as people's informal estimation of the probability of an event happening combined with an evaluation of how concerned they 


\section{PRESERVICE TEACHERS' RISK PERCEPTIONS AND WILLINGNESS TO USE EDUCATIONAL TECHNOLOGIES: A BELIEF SYSTEM APPROACH}

would be about the negative consequences of such an incident (Sjöberg et al., 2004). Rather than a sensual perception, risk perception is a belief about risk and it thus is close to attitudinal phenomena (Frewer et al., 2004). The scholars in risk psychology literature consider risk both from analytical and from affective sides (e.g., Slovic \& Peters, 2006). They believe the fact that people usually judge new risk sources (items and developments) using limited evidence triggering affective reasoning (Howard, 2011). Such reasoning easily restricts rational thinking based on logic and analysis (Howard, 2011; Kahneman, 2011).

About the nature of risk perceptions, three theoretical explanations have been put forwarded: cultural theory, affect heuristic and psychometric paradigm. Because cultural theory has limited predictive power in the empirical research (Sjöberg, 2000) and because affect heuristic not only covers risks but also contains benefits (Slovic \& Peters, 2006), we focus mainly on psychometric paradigm in the present study. The psychometric paradigm emphasizes that risk is a combination of many factors such as knowledge, dread, control, catastrophic potential, equity, voluntariness and tamper with the nature. Many risk psychology studies have used these factors and the researchers have subsumed them into two dimensions: 'dread' and 'uncertainty' (e.g., Sjöberg et al., 2004). Dread is featured by the potential for catastrophic consequences, the lack of control and inequitable distribution of risk. The uncertainty theme is based mainly on the delayed mechanism of the harm, unobservable dangers and the newness of the problem (Sohn, Yang, \& Kang, 2001).

\section{Previous Research}

\section{Teachers' resistance to technology integration}

Even though many countries have invested enormous money in technology-integrated schools, most of them have encountered a big gap between their infrastructure-based policies and intended end goal (i.e., technologically literate citizens): Teachers' resistance. Because most of the countries have not taken teachers' resistance-based belief systems about these educational reforms into account, these investments have produced never used technological tools or tools that are used only for simple learning goals such as presentations, drill-andpractice activities and recognition of words (OECD, 2015).

Such unintended developments have triggered many researchers around the world to understand the factors influencing teachers' resistance to meaningful Ets use. This body of knowledge has showed that four belief clusters are responsible for the resistance. First cluster is related to teacher epistemologies (beliefs about knowledge and knowing) (e.g., Mama \& Hennessy, 2013). When the teachers feel that Ets do not contribute to their traditional teaching based on knowledge transfer (Hanley et al., 2002) or they consider the Ets as tools for easing the presentation of conceptions (Eteokleous, 2008), they easily produce resistance to meaningful Ets use (Hermans et al., 2008). Second cluster is related to teaching efficacy. When the teachers have limited mastery and vicarious experience due to lack of technology-oriented educational opportunities (Paraskeva, Bouta, \& Papagianni, 2008), they have limited technology-focused skills and competences due to limited exposure to and interest in technologies in both daily life (Wozney, Venkatesh, \& Abrami, 2006) and professional life (Hermans et al., 2008) and they are included in an unsupported school environment (Hsu \& Kuan, 2013), they produce resistance. Third belief cluster is about student learning. When the teachers believe that technology integration would not contribute to student learning (O'bannon \& Thomas, 2014) or even disturb it (Gülcü, 2014) and they experience limited gains after their trials (Howard, 2013), they produce resistance to Ets use. The last belief cluster is regarding the evaluations of external resources. When the teachers experience lack of technological tools, limited technical support (Zhao, Pugh, Sheldon, \& Byers 2002) and feel anxieties due to time limitations, curricular pressures (O'bannon \& Thomas, 2014), they produce resistance. Perhaps because of connected nature of belief system (Rokeach, 1968), these belief clusters inform each other on daily base (Kilinc et al., 2017) and direct teachers not to use Ets.

\section{Teachers' risk perceptions about ets use}

Even though the researchers have successfully uncovered the belief clusters causing resistance to change, they seem to miss (Howard, 2013) an important psychological paradigm that is responsible for resistance to anything new: Risk perceptions. Several researchers have mentioned these beliefs as 'factors' or 'barriers'. Earle (2002), for example, 
noted that teachers considered access, time, support, resources and training as extrinsic barriers, whereas attitudes, beliefs and practice are intrinsic barriers. Some have used the 'concern' terminology. O'bannon and Thomas (2014), for example, listed teachers' concerns about Ets use: access, cheating, cyberbullying, disruption of class, negative impact of texting on writing, sexting and access to inappropriate content. Some researchers have preferred the term 'anxiety'. Moran, Hawkes and Gayar (2010), for example, noted that teachers' anxiety was a negative factor for tablet PC integrations. Teachers argued that they felt apprehensive about tablets, that it scared them to think they could lose a lot of information and that they hesitated to use them for fear of making mistakes.

Different from these terminologies, several researchers have used 'risk-oriented' terminologies for denominating these psychological components. Offir and Katz (1990), for example, examined the relationship between elementary school teachers' attitudes towards Ets use and the level of 'risk-taking'. They noted that high risk-taker teachers were more positive about Ets use than medium- and low-level risk takers. In addition, Timucin (2009) investigated teachers' 'risk-related beliefs' about adoption of a computer assisted learning. He uncovered certain risk themes such as feeling of resentment and uncertainty, fear about using technology, concerns about being outcasts in teaching and aversion to risking established teacher careers.

Finally, Howard (2011, 2013) and Kilinc et al. (2016) have used 'risk perceptions' for characterizing the psychological structures causing resistance to Ets use and benefited from risk psychology theories. Howard (2011) scrutinized teachers' technology-related risk perceptions using an 'affect heuristic model'. She argued that teachers with a positive affect toward ETs use perceived low risks and high benefits. In addition, these teachers were risktakers, had high levels of computer efficacy and used student-centered discourse relative to those with negative affect. In one another research, Howard (2013) associated risk perceptions with teachers' resistance to change in the case of technology integration. Her framework this time was based on appraisal theory and cost-benefit analysis. She found that decision not to integrate technology was related to a combination of negative feelings about technology as well as an aversion to risk-taking in teaching. Regarding teachers' willingness to use Ets, Kilinc et al. (2016) incorporated risk perceptions into a decomposed Theory of Planned Behavior (TPB) model. They benefited from 'psychometric paradigm' as a theoretical framework. The results showed that PTs did not find Ets overly risky. In addition, risk perceptions mediated the relationships between independent components in TPB model (attitude, subjective norm and perceived behavioral control) and willingness to use Ets.

\section{Purpose and Research Questions}

Given the theoretical framework and previous research, we can clearly argue that many teachers are resistant to educational reforms because these reform activities do not match with their existing belief systems (Kilinc et al., 2017; Rodriquez, 2005). This resistance is particularly observed in the case of technology integration (Howard, 2013). Even though the governments and international standards emphasize the importance of educating technological literate citizens who can cope with the challenges of 21 st century and governmental bodies have invested enormous money for infrastructures, most of the teachers do not meaningfully integrate Ets into their teaching (e.g., OECD, 2015). Although the researchers have investigated teachers' beliefs (e.g., teacher epistemology) causing resistance to technology integration, an important psychological paradigm (i.e., risk perception) that has potential to explain the relationships between these belief structures and resistance seems to be missed. Only a handful of researchers have benefited from risk-oriented terminologies. These limitations, the necessity of taking urgent steps due to increasing governmental pressures on new generation skills and increasing resistance to Ets use among teachers were starting points of present study. At this point, the purpose of present study was to understand the predictive power of PT's risk perceptions for willingness to use Ets by using a sound risk perception theory (psychometric paradigm). Given this goal, following research question directed our research inquiry: Do PTs' risk perceptions predict their willingness to use Ets? 


\section{PRESERVICE TEACHERS' RISK PERCEPTIONS AND WILLINGNESS TO USE EDUCATIONAL TECHNOLOGIES: A BELIEF SYSTEM APPROACH}

\section{Context and Sample}

\section{Method}

We believe that Turkey is a good laboratory environment in order to understand PTs' and in-service teachers' belief systems and risk perceptions about Ets. Ministry of National Education (MNE, 2014), for example, has launched FATIH Project (Movement of Enhancing Opportunities and Improving Technology) in order to enhance equality to access knowledge among the regions and to enhance technology use in K-12 classrooms (Kilinc et al., 2016). Since 2012, smart boards for each classroom and student and teacher tablets have been distributed to all high schools. In addition, MNE has provided in-service education about efficient technology integration to high school teachers.

On the other hand, there are two directions for becoming a teacher in Turkey. In the first option (e.g, Teaching Biology major), candidates apply to Faculties of Education and are exposed to subject-matter and pedagogy courses. In the second option (e.g., Biology major), the graduates of Science and Arts apply to Faculties of Education in order to take pedagogy courses in the duration of a year (called the Formation). We selected our sample from the PTs in the Formation period at a Turkish University. The convenience sampling procedures were adopted. We first administered our questionnaires to 431 PTs. We excluded six participants due to limited data. Therefore, we used a total of 425 PTs' responses. 86 males $(20.2 \%)$ and $330(77.6 \%)$ females constituted this sample (Nine PTs have not selected any gender [2.2\%]). The mean age was $26.9(\mathrm{SD}=5.17$, Range $=20-48) .185(43.5 \%)$ PTs were from non-STEM branches (e.g., Turkish Literature, Philosophy, Sociology, Psychology, Religious Studies, etc.), whereas 240 (56.5\%) PTs were from STEM branches (e.g., Mathematics, Physics, Chemistry, Biology, Engineering, etc.).

\section{Data Collection Tool}

We developed a questionnaire titled 'Risk Perceptions and Willingness to Use Ets (RPWUE)'. The questionnaire covered three sections: Personal Information, Willingness to Use Ets and Risk Perceptions. In the first section, we asked PTs to fill their personal information regarding field of study (graduated major), gender, age, the number of owned digital technologies (they selected following options as much as they have: PC, lap-top, netbook, flash-memory, scanner, mobile phone, tablet PC, external hard drive, printer and none) and the frequency of Ets use in previous teaching experience (they selected one of the following options: Never, 1-2 times, 3-4 times, 5-10 times and More than 10 times). We selected these components of personal information because previous findings (e.g., Paraskeva et al., 2008 for study field; Tsai \& Tsai, 2010 for the gender; O'bannon and Thomas (2014) for age; Almerich, Orellana, Suárez-Rodríguez and Díaz-García (2016) for the number of owned digital technologies; Hermans et al., 2008 for the frequency of Ets use in previous teaching) repeatedly showed that they are important predictors of Ets use.

The second section included items about 'willingness to use Ets'. For uncovering this willingness, we used five items (e.g., I intend to use ETs as a teacher) that were previously designed by us (Kilinc et al., 2016). The response alternatives here were 'I completely agree', 'I agree', 'Neither agree and nor disagree', 'I agree' and 'I completely agree'.

For the last section covering risk perceptions, we applied procedures of questionnaire development. We first conducted semi-structured interviews with 13 PTs at the same university where we administered the questionnaires. Out of 13, seven PTs were from Science Teaching major and six were from Social Studies Teaching major. We asked two questions addressing possible risk perceptions about Ets use and being informed by psychometric paradigm (Sjöberg et al., 2004) (Question 1: Do you find using Ets risky? If yes, what kind of risks do you feel? If no, why? Question 2: What uncertainties do you feel about your future Ets use). Two authors of present study independently scrutinized this data. We selected frequently used risk-oriented sentences in the transcripts. We then put the selected sentences together and finalized a draft version of Risk Perceptions subquestionnaire. This draft form included 60 items with response alternatives 'Absolutely not', 'Very little', 'Rather little', 'To some extent', 'To a rather high degree', 'To a high degree' and 'To a very high degree'. A team of three experts (one who was expert on instructional 
technologies, one who was expert on Turkish Language and Literature and one who was expert on statistics and questionnaire development), three doctoral students and three PTs from the Formation scrutinized the items in terms of clarity, content and language. After this group's suggestions, we excluded 12 items. Final version of this sub-questionnaire included 48 items.

The RPWUE questionnaire were administered in normal classroom conditions with the help of course lecturer. The PTs were reminded that all ethical procedures were completed and the participation was voluntary. The completion of questionnaires took approximately 25 minutes.

\section{Data Analys is}

In order to examine the reliability and validity of RPWUE questionnaire, alpha scores and factorial structures were calculated. In factor analysis, we benefited from Principal Components Factor Analysis (PCFA) with Varimax rotations (Tabachnick \& Fidell, 2001). In addition, we used descriptive measures such as mean scores, standard deviations and ranges. For responding our research question, we used Hierarchical Regression Analysis. In addition, because we were willing to understand 'clear' predictive power of risk perceptions for willingness to use Ets, we controlled personal variables that were significant predictors in previous research.

\section{Results}

\section{Preliminary Analyses}

The descriptive results about preservice teachers' willingness to use ETs showed that they were very enthusiastic. As shown in Table 1, the features of these technologies such as making teaching easier and achieving a better teaching as well as PTs' intention to try new things seemed to be influential factors in their willingness.

Table 1. Descriptive results about willingness to use Ets

\begin{tabular}{lll}
\hline Willingness to use ETs (Alpha Score =.93) & Mean & SD \\
\hline I intend to use ETs as a teacher. & 4.35 & 0.86 \\
I want to use ETs in my classroom in order to achieve better teaching. & 4.28 & 0.90 \\
I am willing to use ETs because I like learning new things. & 4.20 & 0.90 \\
I am keen to use ETs in my classroom because I believe that they make teaching easier. & 4.19 & 0.93 \\
\hline
\end{tabular}

On the other hand, we conducted PCFA with Varimax rotation in order to determine the factorial structure of Risk Perception sub-questionnaire. We excluded 13 items due to low factorial values, joint factor loadings and reliability problems after six iterations. As shown in Table 2, the final PCFA yielded six factors: dread (10 items; $15.55 \%$ variance), noneducational goals (6 items; $12.57 \%$ variance), ne gative impacts on learning (6 items; 10.19 $\%$ variance), unnatural consequences (6 items; $8.87 \%$ variance), first time use (2 items; 6.22 $\%$ variance) and traditional education ( 3 items; $5.1 \%$ variance). These factors predicted \% 58.51 variance on Risk Perception sub-questionnaire. In addition, the reliability scores of the factors ranged from 0.56 to 0.95 .

Looking at descriptive results in Table 2, it seems that PTs found using Ets slightly risky. In terms of dread, most of PTs considered that the existence of limited knowledge about integration of Ets would not make them anxious. They particularly emphasized that students' prior knowledge about technologies might trouble them. Both students with sophisticated knowledge and those with limited knowledge seemed to be sources of risk because former group might not like the teaching materials and latter group might need extra attention. In addition, it seems that the feeling of being responsible due to technical problems of Ets made PTs anxious. However, they did not consider that they would feel embarrassment when they experienced these problems. When it comes to non-educational goals, the possibility of using Ets only for entertainment and for accessing social media sites moderately made PTs anxious. In addition, accessing illegal websites yielded the lowest risk score in this factor. 


\section{PRESERVICE TEACHERS' RISK PERCEPTIONS AND WILLINGNESS TO USE EDUCATIONAL TECHNOLOGIES: A BELIEF SYSTEM APPROACH}

Table 2. Descriptive results and factor loads in Risk Perception sub-questionnaire

\begin{tabular}{|c|c|c|c|}
\hline Factorial S tructures & Mean & SD & Factor loads \\
\hline \multicolumn{4}{|l|}{ Dread $($ Alpha Score $=.88)$} \\
\hline $\begin{array}{l}\text { 18. To what extent does the possibility of existence of the students who know } \\
\text { technology better than you in the classroom make you anxious? }\end{array}$ & 2.41 & 1.40 & .62 \\
\hline $\begin{array}{l}\text { 19. To what extent do you feel embarrassed if you experience problems while using } \\
\text { technologies? }\end{array}$ & 2.33 & 1.39 & .71 \\
\hline $\begin{array}{l}\text { 21. To what extent will you struggle in adapting to new ETs considering rapid } \\
\text { technological developments? }\end{array}$ & 2.81 & 1.22 & .55 \\
\hline $\begin{array}{l}\text { 26. To what extent will you struggle in preparing the digital learning environments } \\
\text { that would be liked by students who enjoy the digital technologies? }\end{array}$ & 3.28 & 1.08 & .46 \\
\hline 31. To what extent may you lose face in the classroom unless every thing goes well? & 2.33 & 1.16 & .63 \\
\hline $\begin{array}{l}\text { 32. To what extent does the possibility of technologies' breaking down during the } \\
\text { course make you anxious? }\end{array}$ & 2.43 & 1.35 & .79 \\
\hline $\begin{array}{l}\text { 33. To what extent does that you have limited knowledge about certain ETs make } \\
\text { you anxious? }\end{array}$ & 2.75 & 1.31 & .81 \\
\hline $\begin{array}{l}\text { 34. To what extent does that you have limited knowledge about integrating certain } \\
\text { ETs into your teaching make you anxious? }\end{array}$ & 2.87 & 1.30 & .78 \\
\hline $\begin{array}{l}\text { 47. To what extent does that some students have limited knowledge about } \\
\text { technology use make you anxious? }\end{array}$ & 3.17 & 1.31 & .57 \\
\hline $\begin{array}{l}\text { 48. To what extent does the idea of being responsible for the technical problems in } \\
\text { ETs make you anxious? }\end{array}$ & 3.14 & 1.42 & .62 \\
\hline \multicolumn{4}{|l|}{ Non-Educational Goals $($ Alpha S core $=.85)$} \\
\hline $\begin{array}{l}\text { 2. To what extent does using ETs in the classroom make students to access illegal } \\
\text { web sites? }\end{array}$ & 3.26 & 1.40 & .58 \\
\hline 15. To what extent do the students use ETs only for entertainment? & 3.76 & 1.33 & .70 \\
\hline 24. To what extent do the students use ETs for non-educational goals? & 3.68 & 1.39 & .77 \\
\hline 25. To what extent do the students break the passwords of the tablets & 3.70 & 1.36 & .57 \\
\hline $\begin{array}{l}\text { 27. To what extent does using ETs in the classroom make your students to access } \\
\text { game sites? }\end{array}$ & 3.67 & 1.34 & .81 \\
\hline $\begin{array}{l}\text { 30. To what extent does using ETs in the classroom make your students to access } \\
\text { social media sites such as Facebook? }\end{array}$ & 3.82 & 1.52 & .75 \\
\hline \multicolumn{4}{|l|}{ Negative Impacts on Learning (Alpha Score $=.82$ ) } \\
\hline $\begin{array}{l}\text { 20. To what extent does ETs make the social relationships among your students to } \\
\text { fade? }\end{array}$ & 3.30 & 1.46 & .50 \\
\hline 22. To what extent does students' gazing on visuals in ETs distract them? & 2.99 & 1.24 & .73 \\
\hline 29. To what extent does using ETs fade your students' interest in the course? & 2.86 & 1.25 & .60 \\
\hline 36. To what extent does using ETs make your students free rider? & 4.00 & 1.22 & .44 \\
\hline classroom cause loss of time? & 2.59 & 1.17 & .61 \\
\hline 41. To what extent using ETs negatively affect student learning? & 2.83 & 1.10 & .63 \\
\hline \multicolumn{4}{|l|}{ Unnatural Consequences (Alpha $S$ core $=.83$ ) } \\
\hline $\begin{array}{l}\text { 1. To what extent does using ETs in the classroom cause the illnesses such as } \\
\text { cancer? }\end{array}$ & 2.78 & 1.10 & .77 \\
\hline $\begin{array}{l}\text { 12. To what extent does using ETs mean destroying the natural classroom } \\
\text { environment? }\end{array}$ & 2.97 & 1.32 & .44 \\
\hline $\begin{array}{l}\text { 13. To what extent do you think that the risks stemming from using ETs increase } \\
\text { over time? }\end{array}$ & 3.22 & 1.26 & .53 \\
\hline 14. To what extent does using ETs have the risks unknown today? & 3.46 & 1.08 & .64 \\
\hline 17. To what extent does using ETs expose radiation to students? & 3.37 & 1.23 & .78 \\
\hline 28. To what extent does using ETs cause eye diseases? & 3.72 & 1.21 & .49 \\
\hline \multicolumn{4}{|l|}{ Traditional Education $($ Alpha Score $=.56)$} \\
\hline $\begin{array}{l}\text { 35. To what extent do the parents prefer traditional education that is shaped by } \\
\text { national examinations to using ETs in the classrooms? }\end{array}$ & 3.64 & 1.32 & .65 \\
\hline $\begin{array}{l}\text { 38. To what extent do your students prefer traditional education that is shaped by } \\
\text { national examinations to using ETs in the classrooms? }\end{array}$ & 2.82 & 1.28 & .56 \\
\hline $\begin{array}{l}\text { 40. To what extent do the principals support traditional education that is shaped by } \\
\text { national examinations to using ETs in the classrooms? }\end{array}$ & 3.69 & 1.18 & .79 \\
\hline \multicolumn{4}{|l|}{ First time use (Alpha S core $=.95)$} \\
\hline 4. To what extent does using ETs first time make you frighten? & 2.47 & 1.31 & .86 \\
\hline 5. To what extent does using ETs first time in FATIH Project make you anxious? & 2.47 & 1.28 & .85 \\
\hline
\end{tabular}


In the case of negative impacts on learning, PTs moderately believed that Ets would negatively affect student learning. They strongly believed that Ets would make students free riders and would fade the social relationships among the students. They also moderately believed that Ets might distract students. On the other hand, they did not strongly believe that Ets would lead the loss of time. In terms of unnatural consequences, they moderately thought that Ets would destroy natural classroom environment. They thought that these technologies might cause eye diseases. In addition, they believed that Ets might have unknown risks that might emerge in the future. They also believed that Ets might expose radiation to students not as much as they thought that these technologies might cause cancer. Regarding traditional education, they moderately believed that students, parents and principals might prefer traditional education (i.e., didactic teaching without Ets) to Ets because of national examinations. Finally, it seems that first time use of Ets did not make PTs anxious.

\section{The predictive power of risk perceptions for willingness to use ETs}

We conducted hierarchical regression in order to understand the predictive power of risk perceptions for willingness to use Ets. We entered personal variables such as gender, age, field of study, the number of owned digital devices and the frequency of Ets use in previous teaching experience in the first step. We incorporated risk perception factors into the model in the second step. The results of this regression were presented in Table 3.

Table 3. The results of first regression

\begin{tabular}{|c|c|c|c|c|c|}
\hline \multirow{3}{*}{ Step 1} & \multirow[b]{2}{*}{ Variables } & \multicolumn{4}{|c|}{ Willingness to use ETs } \\
\hline & & $\mathrm{B}$ & SE & Beta & $p$ \\
\hline & Gender & 0.96 & 0.41 & $0.12 *$ & 0.02 \\
\hline \multirow{16}{*}{ Step 2} & Age & 0.01 & 0.03 & 0.01 & 0.88 \\
\hline & Field of Study & -0.16 & 0.34 & -0.02 & 0.64 \\
\hline & The number of digit devices & 0.29 & 0.09 & $0.17 *$ & 0.01 \\
\hline & The frequency of tech. use & 0.03 & 0.11 & 0.01 & 0.78 \\
\hline & Gender & 1,09 & 0,41 & $0,13 *$ & 0,01 \\
\hline & Age & $-0,02$ & 0,03 & $-0,04$ & 0,46 \\
\hline & Field of Study & $-0,02$ & 0,32 & $-0,01$ & 0,94 \\
\hline & The number of digit devices & 0,28 & 0,09 & $0,16 * *$ & 0.00 \\
\hline & The frequency of tech. use & $-0,04$ & 0,11 & $-0,02$ & 0,71 \\
\hline & Traditional Education & 0,12 & 0,06 & $0,10 *$ & 0,05 \\
\hline & First time use & $-0,04$ & 0,07 & $-0,03$ & 0,61 \\
\hline & Unnatural consequences & $-0,11$ & 0,04 & $-0,18 * *$ & 0,01 \\
\hline & Negative impacts on learning & $-0,15$ & 0,04 & $-0,25 * *$ & 0.00 \\
\hline & Non-educational goals & $-0,01$ & 0,03 & $-0,01$ & 0,94 \\
\hline & Dread & 0,02 & 0,02 & 0,04 & 0,51 \\
\hline & & \multicolumn{4}{|c|}{$\begin{array}{l}\text { Step 1: } \mathrm{R}^{2}=0.04, \mathrm{~F}(5,385)=3.162, \\
\mathrm{p}<0.01, \text { Step } 2: \mathrm{R}^{2}=0.17, \mathrm{~F}(11,379)= \\
6.940, \mathrm{p}<0.001\end{array}$} \\
\hline
\end{tabular}

Table 3 showed that gender $(\beta=0.12, p<0.05)$ and the number of owned digital devices $(\beta=0.17, p<0.05)$ were significant positive predictors of willingness to use Ets. Specifically female PTs and those with high number of digital devices seemed to be more intended to use ETs. In addition, the personal variables in the first step explained $4 \%$ total variance. When the risk perception factors were added into the model, we noticed that these factors significantly contributed to the variance $\left(R^{2}=0.17, F(11,379)=6.940, p<0.001\right)$. Among these factors, traditional education was a significant positive predictor $(\beta=0.10, \mathrm{p}=$ $0.05)$, whereas unnatural consequences $(\beta=-0.18, \mathrm{p}<0.05)$ and negative impacts on learning $(\beta=-0.25, \mathrm{p}<0.05)$ were significant negative predictors. Perhaps those strongly believing the risk of stakeholder's preference would be traditional education over Ets use were more willing to use Ets. In addition, those strongly believing the risk of Ets would 


\section{PRESERVICE TEACHERS' RISK PERCEPTIONS AND WILLINGNESS TO USE EDUCATIONAL TECHNOLOGIES: A BELIEF SYSTEM APPROACH}

negatively affect student learning and those strongly believing the risk of Ets use would produce unnatural consequences had less intention to use Ets. In addition, gender $(\beta=0.13, p$ $<0.05)$ and the number of owned digital devices $(\beta=0.16, \mathrm{p}<0.05)$ were still positive predictors in the second step.

Table 4. The results of second regression

\begin{tabular}{|c|c|c|c|c|c|}
\hline & & \multicolumn{4}{|c|}{ Willingness to use ETs } \\
\hline & Variables & $\mathrm{B}$ & SE & Beta & $\mathrm{p}$ \\
\hline Step 1 & Traditional Education & -0.08 & 0.07 & -0.06 & 0.26 \\
\hline \multirow[t]{2}{*}{ Step 2} & Traditional Education & 0.12 & 007 & 0.08 & 0.09 \\
\hline & Negative impacts on learning & -0.28 & 0.04 & -0.37 & 0.00 \\
\hline \multirow[t]{3}{*}{ Step 3} & Traditional Education & 0.13 & 0.07 & 0.09 & 0.09 \\
\hline & Negative impacts on learning & -0.22 & 0.05 & -0.30 & 0.00 \\
\hline & Unnatural consequences & -0.09 & 0.05 & -0.11 & 0.08 \\
\hline \multirow[t]{4}{*}{ Step 4} & Traditional Education & 0.14 & 0.07 & 0.10 & 0.05 \\
\hline & Negative impacts on learning & -0.21 & 0.05 & -0.28 & 0.00 \\
\hline & Unnatural consequences & -0.09 & 0.05 & -0.12 & 0.06 \\
\hline & The number of digit device & 0.33 & 0.10 & 0.15 & 0.00 \\
\hline \multirow[t]{6}{*}{ Step 5} & Traditional Education & 0.13 & 0.07 & 0.09 & 0.07 \\
\hline & Negative impacts on learning & -0.20 & 0.05 & -0.27 & 0.00 \\
\hline & Unnatural consequences & -0.10 & 0.05 & -0.14 & 0.03 \\
\hline & The number of digit device & 0.35 & 0.10 & 0.16 & 0.00 \\
\hline & Gender & 1.07 & 0.46 & 0.11 & 0.02 \\
\hline & $\begin{array}{l}\text { Step 1: } \mathrm{R}^{2}=0.03, \mathrm{~F}(1,398)= \\
1.263, \\
\mathrm{p}>0.01, \text { Step } 2: \mathrm{R}^{2}=0.12, \mathrm{~F}(2, \\
397)=28.311, \mathrm{p}<0.001, \text { Step } 3: \\
\mathrm{R}^{2}=0.13, \mathrm{~F}(3,396)=20.031, \\
\mathrm{p}<0.01, \text { Step } 4: \mathrm{R}^{2}=0.15, \mathrm{~F}(4, \\
\text { 395) }=18.130, \mathrm{p}<0.01, \text { Step 5: } \\
\mathrm{R}^{2}=0.17, \mathrm{~F}(5,394)=15.724, \\
\mathrm{p}<0.01\end{array}$ & & & & \\
\hline
\end{tabular}

In the first regression, consistent with existing literature (e.g. Eteokleous, 2008), we expected that traditional education factor would negatively predict willingness to use Ets because we believed that as PTs considered the risk of stakeholders would prefer traditional education to Ets use, they would have less intention to Ets use. Because we confronted a positive beta score $(\beta=0.10)$, which was an unexpected result, we run second regression for thoroughly understanding the predictive power of traditional education. Here, we benefited only from significant predictors of first regression. We added them one by one through five steps as shown in Table 4. When we added traditional education into model in first step, it yielded an insignificant negative beta score $(\beta=-0.06, p>0.05)$. This fitted with our expectation. However, as we added other risk perception factors into the model one by one (in steps 2 and 3), we noticed that other significant negative predictors suppressed the predictive power of traditional education and made it a positive predictor $(\beta=0.08, \mathrm{p}>0.05$ in the second step; $\beta=0.09, p>0.05$ in the third step). The incorporation of significant personal variables into the models in following steps did not saliently change this picture.

\section{Discussion}

The purpose of present study was to understand the predictive power of PTs' risk perceptions for willingness to use Ets. We first developed a valid and reliable questionnaire and administration of this questionnaire resulted in six factors: dread, non-educational goals, negative impacts on learning, unnatural consequences, first time use and traditional education. Even though many studies adopting psychometric paradigm produced two main 
factorial structures (dread and uncertainty) (Sjöberg et al, 2004), our distribution of factors was acceptable because some researchers found similar themes such as 'tamper with the nature' and 'negative impacts' in previous risk psychology studies (Sjöberg, 2000).

We can argue that PTs found Ets slightly risky. Looking at risk perception factors, dread, for example, seems to be related to belief cluster about teaching efficacy that was uncovered in existing literature (e.g., Timucin, 2009) Most of PTs considered that limited knowledge about integration of Ets would not make them anxious perhaps because they trusted on their mastery experience on similar technologies at home (e.g., Almerich et al., 2016). Some PTs believed students' knowledge level (high or low) might trouble them. Feeling responsible for technical problems was one another dread source (Moran et al., 2010). Perhaps PTs' limited technical abilities and limited pedagogical repertoires on how to deal with students with extreme knowledge levels (Howard, 2013) were the sources of the risks in their minds.

The non-educational goals seem to be related to belief cluster about student learning in existing literature (e.g., O'bannon \& Thomas, 2014). Like the teachers considering that Ets might disturb student learning in previous studies (e.g., Gülcü, 2014), some PTs in the present study considered that students might use Ets for entertainment and accessing social media. Even though accessing illegal websites yielded lowest score, we can argue that this non-educational goal was expressed by many teachers in different countries (e.g., Kilinc et al., 2016). We believe that these risk sources were particularly related to teachers' understandings about the control mechanisms. Even though they may be aware of filtering systems, they may not be aware of whether the schools use these them.

The negative impacts on learning was also related to belief cluster about student learning in existing literature (e.g., Mama \& Hennessy, 2013). PTs moderately believed that Ets would negatively influence student learning. Fading social relationships, distraction and making students free riders were highly agreed items. Similar findings were observed in many previous studies (e.g., Moran et al., 2010; O'bannon \& Thomas, 2014), meaning that these impacts are easily recognizable and personally experienced by the teachers. In addition, even though loss of time was one of the top risks suggested by experienced teachers (e.g., Earle, 2002), PTs in the present study did not find this possibility risky perhaps because most of them did not have a real teaching experience where they need to have an efficient time management.

The factor unnatural consequences seem to be different from belief clusters existing in previous findings. It is close to 'uncertainty' dimension in psychometric paradigm (Sohn et al., 2001). Even though the item about destroying natural classroom environment may be related to belief cluster about teacher epistemology (i.e., teacher-centered learning and knowledge transfer), we can argue that particularly unnatural results come together in this factor. Consistent with some resistant teachers (e.g., Howard, 2013), PTs moderately believed that Ets would destroy natural classroom environment perhaps because they envisaged a classroom including materials such as blackboard, books, notebooks and pencils with which they studied in their previous schooling years (Gülcü, 2014). Most of the other items in this factor were related to health. They agreed that Ets might cause eye diseases and radiation. However, they did not believe that these technologies would cause cancer. Perhaps PTs experienced similar technologies for long time and did not produce any cause-effect reasoning with cancer due to long time exposure and resulting no illness (Kilinc et al., 2016).

Traditional education was related to belief cluster about teacher epistemology. Previous findings repeatedly showed that some teachers preferred teacher-centered learning and gave importance to the knowledge transfer due to the nature of national examinations (Eteokleous, 2008; Mama \& Hennessy, 2013). These findings are consistent with the nature of school culture in Turkey due to centralized examination system (Kilınç, Watt, \& Richardson, 2012). PTs in the present study seem to be concerned regarding students', teachers' and principals' expectations of traditional education based on transfer of scientific truths and solving test questions. Perhaps their similar experience in previous schooling years also enhanced this mentality. 


\section{PRESERVICE TEACHERS' RISK PERCEPTIONS AND WILLINGNESS TO USE EDUCATIONAL TECHNOLOGIES: A BELIEF SYSTEM APPROACH}

First time use was related to belief cluster about teaching efficacy. In previous studies, the teachers with lack of knowledge and of skills about Ets use felt anxious for their first time use (Paraskeva et al., 2008). However, PTs in the present study did not feel same problem. In risk psychology research, the researchers repeatedly found that novices were stronger risk takers than experienced people perhaps because of their limited negative experience and knowledge-seeking nature of humans (Taylor, 2010). This finding might explain our first time user PTs' strong enthusiasm.

Looking at predictive power of risk perceptions for willingness to use Ets, regression results showed that certain personal variables were significant predictors. The gender and the number of owned digital technologies were significant positive predictors of willingness to use Ets. Even though our research question was not particularly related to personal variables, we can argue that these two important parameters deserve further attention.

When it comes to risk perceptions, underlying analysis unit of present study, we noticed that they contributed to the variance in willingness to use Ets (13\% variance contribution). In other words, risk perceptions are crucial factors determining willingness to use Ets.

We can firstly say that first time use and noneducational goals were not significant predictors of our dependent variables. The PTs had already not found first time use as a source of risk and perhaps their risk-taking nature (Offir \& Katz, 1990), eliminated the impact of this dimension on the willingness to use Ets. In the case of noneducational goals such as accessing illegal websites, even though they might have moderate risk perceptions on these components, we believe that they may feel confidence for using 'control' and 'filter' mechanisms when it comes to practice.

Traditional education was an intriguing risk perception dimension that was struggled us to understand. In the first regression, it was a positive predictor of willingness to use Ets. Before looking at our second regression results, we first thought that perhaps PTs wanted to cope with students', parents' and principals' traditional education-based expectations as they considered that examination-based traditional education would destroy a student-centered learning environment where Turkish teacher educators strongly promoted in the Formation courses. Such 'Robin Hood effect' was also observed in one of our previous studies (Kılınç et al., 2013). However, the results of second regression reminded us to completely revise our mentality. When we incorporated traditional education as a single predictor, it was a significant negative predictor of willingness to use Ets. However, when we added negative impacts on learning into first model, this additional dimension suppressed the beta value of traditional education and traditional education became a positive predictor (even though the score was insignificant). Similarly, unnatural consequences stemming from trying something new enhanced positive prediction of traditional education in the third step. These results may mean that PTs possessed a core, central belief about teacher epistemology that was based on traditional education with limited (or without) Ets use. In the first step, PTs were willing to adopt stakeholders' preference (traditional education that is shaped by examination system) because it fits well with their own core belief. As they agreed stakeholder's preference, they did not want to use Ets (perhaps they had already not wanted to use technologies). Considering nested nature of beliefs (Kilinc et al., 2017), when we added negative impacts of Ets on learning and unnatural consequences to traditional education to the model, perhaps PTs felt that Ets use might destroy their important traditional learning environment (these two dimensions decreased their willingness to use ETs) (Hanley et. al., 2002; O'bannon \& Thomas, 2014) and they therefore wanted to take the ropes at hand and managed these negative impacts by enhancing their own technology use (Traditional Robin Hood effect). We can speculate that we discovered a small belief system including four beliefs after this calculation. Core belief was traditional education with limited or without Ets use. Peripheral beliefs were beliefs about stakeholders' preference, beliefs about impacts of Ets use on student learning and beliefs about unnatural consequences of Ets use.

It is easy to interpret the findings about other risk perception dimensions after this stage. If we remember again, perhaps most of the PTs had a traditional learning environment with limited or without Ets use in mind. The items in unnatural consequences and negative impacts on learning may be understood in terms of negative influences on a traditional 
environment though we first thought that PTs might consider a student-centered environment with a meaningful Ets integration (Ertmer \& Ottenbreit-Leftwich, 2010). Bearing this new perspective in mind, we can argue that unnatural consequences such as destroying 'natural classroom environment' (i.e., 'their desired traditional learning environment') and resulting health-based problems caused them not to use Ets. Same reasoning can also be used for negative impacts on learning. Distraction and becoming free-riders sound threats to a traditional learning environment because students need to gaze what the teachers tell and write as well as they need to memorize the conceptions so their minds need to efficiently work. Therefore, such threats of Ets use resulted in the decrease in willingness to use Ets.

\section{Implications}

We took two lessons from present study. And these lessons might be turned into applications about professional development. First, yes, we need reform policies in order to produce a balance among science, technology and society and to provide efficient and healthy lives for humans (NEA, 2008; ISTE, 2008). However, the reform efforts specifically about technology integration in our case need to take teachers' belief systems into account (Fives \& Buehl, 2012). Present study taught us that particularly certain core, central beliefs such as beliefs about teacher epistemology, beliefs about student learning and beliefs about teaching efficacy work together in the case of technology integration. Particularly a core, central belief that is based on traditional education (i.e. didactic teaching for knowledge transfer) with limited or without Ets use seem to invade a big portion of our Turkish PTs' belief system. Even though teacher epistemology are harder to change than peripheral versions (Gill \& Fives, 2015), we suggest epistemology-oriented sessions to revise this central belief.

Second lesson was related to risk perceptions and risk mitigation strategies. Even though it seems that PTs in the present study looked at risk perception items from a lens of a central belief (traditional education), and even if first job should be destroying this wall, our findings showed that risk perceptions require immediate care because they could easily produce blocks before willingness to use Ets. Risk communication strategies at this point may be helpful. The scholars in risk psychology literature suggest a combination of 'risk as analysis' and 'risk as feeling' approaches (e.g., Slovic \& Peters, 2006). Perhaps our PTs evaluated risk perception items using their schooling experience or their limited experience in Formation period. This limited evidence has the potential to trigger affective reasoning (e.g., Traditional Robin Hood effect) (Howard, 2011) and to restrict rational thinking based on logic and analysis (e.g., Kahneman, 2011). Taken together, even though there is limited research on the (mathematical) risk possibilities of Ets use, such knowledge about negative impacts on learning (e.g., the proportion of students considering that Ets distract them and follow up risk calculations), unnatural consequences (e.g., the proportion of radiation stemming from Ets and follow up risk calculations) and traditional education (e.g., the proportion of parents preferring traditional education over Ets use and follow up risk calculations) can be produced and shared with PTs. In addition to this analytic framework, experienced teachers can be invited to teacher education courses so they share their experience about Ets use and obstacles they encountered. Perhaps these experienced teachers would use an affect-rich language. These narratives and risk possibilities can be discussed with PTs so they change the configurations of their belief systems in the intended direction. 


\section{PRESERVICE TEACHERS' RISK PERCEPTIONS AND WILLINGNESS TO USE EDUCATIONAL TECHNOLOGIES: A BELIEF SYSTEM APPROACH}

\section{References}

Abelson, R. P. (1979). Differences between belief and knowledge systems. Cognitive Science, 3, 355366.

Almerich, G., Orellana, N., Suárez-Rodríguez, J., \& Díaz-García, I. (2016). Teachers' information and communication technology competences: A structural approach. Computers \& Education, 100, 110-125. https://doi.org/10.1016/j.compedu.2016.05.002.

Demirbag, M. \& Kilinc, A. (2015). Beyond TPCK: Exploring a science teacher's technological pedagogical content belief system. Paper Presented at National Association for Research in Science Teaching, Narst 2015 Congress, USA.

Earle, R. S. (2002). The integration of instructional technology into public education: Promises and challenges. Educational Technology-saddle Brook Then Englewood Cliffs nj-, 42(1), 5-13. $\begin{array}{lllll}\text { Retrieved on } & 10 & \text { May } & 2017 & \text { from }\end{array}$ http://isites.harvard.edu/fs/docs/icb.topic87187.files/Earle02.pdf.

Ertmer, P. A., \& Ottenbreit-Leftwich, A. T. (2010). Teacher technology change: How knowledge, confidence, beliefs, and culture intersect. Journal of Research on Technology in Education, 42(3), 255-284. http://dx.doi.org/10.1080/15391523.2010.10782551.

Eteokleous, N. (2008). Evaluating computer technology integration in a centralized school system. Computers \& Education, 5I (2), 669-686. https://doi.org/10.1016/j.compedu.2007.07.004.

Fives, H., \& Buehl, M. M. (2012). Spring cleaning for the 'messy' construct of teachers' beliefs: What are they? Which have been examined? What can they tell us? In: K.R. Harris, \& T. Urdan (eds.) APA educational psychology handbook: Individual differences and cultural and contextual factors (pp.471-499). New York: APA.

Frewer, L., Lassen, J., Kettlitz, B., Scholderer, J., Beekman, V., \& Berdal, K. G. (2004). Societal aspects of genetically modified foods. Food and Chemical Toxicology, 42(7), 1181-1193. https://doi.org/10.1016/j.fct.2004.02.002.

Gill, M. G., \& Fives, H. (2015). Introduction. In H. Fives \& M. G. Gill (Ed.) International handbook of research on teachers' beliefs (pp. 48-66). New York: Routledge.

Gülcü, İ. (2014). Etkileşimli tahta kullanımının avantajları ve dezavantajlarına yönelik öğretmen görüşleri. XVI. Akademik Bilişim Kongresi, 5-7.

Hanley, J. J., Lumpe, A. T., Czerniak, C. M., \& Egan, V. (2002). From beliefs to actions: The beliefs and actions of teachers implementing change. Journal of Science Teacher Education, 13, 171187. https://doi.org/10.1023/A:1016565016116

Hermans, R., Tondeur, J., van Braak, J., \& Valcke, M. (2008). The impact of primary school teachers' educational beliefs on the classroom use of computers. Computers \& Education, 51(4), 14991509. https://doi.org/10.1016/j.compedu.2008.02.001.

Howard, S. K. (2011). Affect and acceptability: Exploring teachers' technology related risk perceptions. Educational Media International, 48, 261-272.

http://dx.doi.org/10.1080/09523987.2011.632275.

Howard, S. K. (2013). Risk-aversion: Understanding teachers' resistance to technology integration. Technology, Pedagogy and Education, 22(3), 357-372. http://dx.doi.org/10.1080/1475939X.2013.802995.

Hsu, S., \& Kuan, P. Y. (2013). The impact of multilevel factors on technology integration: The case of Taiwanese grade 1-9 teachers and schools. Educational Technology Research and Development, 61(1), 25-50. http://dx.doi.org/10.1007/s11423-012-9269-y 
International Society for Technology in Education. (2008). ISTE Standards for Teachers. Retrived on 12 March 2016 from https://www.iste.org/standards/standards.

Kahneman, D. (2011). Thinking, fast and slow. Macmillan: London.

Kılınç, A., Watt, H. M., \& Richardson, P. W. (2012). Factors influencing teaching choice in Turkey. Asia-Pacific Journal of Teacher Education, 40(3), 199-226.

Kılınç, A., Kartal, T., Eroğlu, B., Demiral, Ü., Afacan, Ö., Polat, D., ... \& Görgülü, Ö. (2013). Preservice science teachers' efficacy regarding a socioscientific issue: A belief system approach. Research in Science Education, 43(6), 2455-2475.

Kilinc, A., Ertmer, P., Bahcivan, E., Demirbag, M., Sonmez, A., \& Ozel, R. (2016). Factors Influencing Turkish Preservice Teachers' Intentions to Use Educational Technologies and Mediating Role of Risk Perceptions. Journal of Technology and Teacher Education, 24(1), 3762.

Kilinc, A., Demiral, U., \& Kartal, T. (2017). Resistance to dialogic discourse in SSI teaching: The effects of an argumentation-based workshop, teaching practicum, and induction on a preservice science teacher. Journal of Research in Science Teaching , 54(6), 764-789.

Lee, H., \& Witz, K. G. (2009). Science teachers' inspiration for teaching socio-scientific issues: Disconnection with reform efforts. International Journal of Science Education, 31 (7), 931-960

Mama, M., \& Hennessy, S. (2013). Developing a typology of teacher beliefs and practices concerning classroom use of ICT. Computers \& Education, 68, 380-387. https://doi.org/10.1016/j.compedu.2013.05.022.

Ministry of National Education (2014). MEOIT (FATIH) Project. Retrievedon April 122016 from http://www.fatihprojesi.org/

Moran, M., Hawkes, M., \& Gayar, O. E. (2010). Tablet personal computer integration in higher education: Applying the unified theory of acceptance and use technology model to understand supporting factors. Journal of Educational Computing Research,42(1), 79-101. https://doi.org/10.2190/EC.42.1.d

National Education Association [NEA]. (2008). Technology in schools: The ongoing challenge of access, adequacy, and equity. Retrieved on April 112016 from http://www.nea.org/assets/docs/PB19_Technology08.pdf

O'bannon, B. W., \& Thomas, K. (2014). Teacher perceptions of using mobile phones in the $\begin{array}{llll}\text { classroom: Age matters! Computers \& Education, 74, 15-25. } & \text {. }\end{array}$ https://doi.org/10.1016/j.compedu.2014.01.006.

Offir, B., \& Katz, Y.J. (1990). Computer oriented attitudes as a function of risk taking among Israeli elementary school teachers, Journal of Computer Assisted Learning, 6, 168-173. https://doi.org/10.1111/j.1365-2729.1990.tb00364.x

Organization for Economic Cooperation and Development (OECD) (2015). TALIS 2013 Results: Teaching in Focus BriefNo. 12 - Teaching with technology. OECD Publishing, Paris.

Paraskeva, F., Bouta, H., \& Papagianni, A. (2008). Individual characteristics and computer selfefficacy in secondary education teachers to integrate technology in educational practice. Computers \& Education, 50(3), 1084-1091.

Rodriquez, A. J. (2005). Teachers' resistance to ideological and pedagogical change: Definitions, theoretical framework, and significance. In A. J. Rodriquez \& R. S. Kitchen (Eds.), Preparing mathematics and science teachers for diverse classrooms: Promising strategies for transformative pedagogy (pp. 1-16). Mahwah, NJ: Lawrence Erlbaum Associates, Inc. 


\section{PRESERVICE TEACHERS' RISK PERCEPTIONS AND WILLINGNESS TO USE EDUCATIONAL TECHNOLOGIES: A BELIEF SYSTEM APPROACH}

Rokeach, M. (1968). Beliefs, attitudes, and values: a theory of organization and change. San Francisco: Jossey.

Sjöberg L. (2000). The methodology of risk perception research. Quality and Quantity, 34, 407418. https://doi.org/10.1023/A:1004838806793

Sjöberg, L., Moen, B. E., \& Rundmao, T. (2004). Explaining risk perception: an evaluation of the psychometric paradigm in risk perception research. Trondheim: Rotunde.

Slovic, P., \& Peters, E. (2006). Risk perception and affect. Current Directions in Psychological Science, 15(6), 322-325.

Sohn, K. Y., Yang, J. W., \& Kang, C. S. (2001). Assimilation of public opinions in nuclear decisionmaking using risk perception. Annals of Nuclear Energy, 28(6), 553-563. https://doi.org/10.1016/S0306-4549(00)00076-1.

Tabachnick, B. G., \& Fidell, L. S. (2001). Using multivariate analysis. California State University Northridge: Harper Collins College Publishers.

Taylor, M. E. (2010). Teaching efficacy, innovation, school culture and teacher risk taking. Unpublished doctorate thesis. University of Louis ville. Louis ville, Kentucky.

Timucin, M. (2009). Diffusion of technological innovation in a foreign languages unit in Turkey: A focus on risk-aversive teachers. Technology, Pedagogy, and Education, 18(1), 75-86. http://dx.doi.org/10.1080/14759390802704121.

Tsai, M. J., \& Tsai, C. C. (2010). Junior high school students' Internet usage and self-efficacy: A reexamination of the gender gap. Computers \& Education,54(4), 1182-1192. https://doi.org/10.1016/j.compedu.2009.11.004.

Wozney, L., Venkatesh, V., \& Abrami, P. (2006). Implementing computer technologies: Teachers' perceptions and practices. Journal of Technology and Teacher Education, 14(1), 173-207.

Zhao, Y., Pugh, K., Sheldon, S., \& Byers, J.L. (2002). Conditions for classroom technology innovations. Teachers College Record, 104(3), 482-515. Retrieved on 10 May 2017 from http://crcsalon.pbworks.com/f/Conditions+for+Classroom+Technology+Innovations.pdf 